\title{
Effects of measles on the immune response of Nigerian children
}

\author{
H. C. WHITTLE, ALICE BRADLEY-MOORE, A. FLEMING, and B. M. GREENWOOD \\ From the Departments of Paediatrics, Medicine, and Pathology, Ahmadu Bello University Hospital, Zaria, Nigeria
}

\begin{abstract}
Whittle, H. C., Bradley-Moore, A., Fleming, A., and Greenwood, B. M. (1973). Archives of Disease in Childhood, 48, 753. Effects of measles on the immune response of Nigerian children. The effects of measles on the immune system of Nigerian children were investigated. At the time of the rash, skin tests to tuberculin purified protein derivative, candida, and streptococcal antigens were negative. Skin sensitization with dinitrochlorobenzene and lymphocyte transformation by phytohaemagglutinin were normal. Antibody response to the $\mathrm{H}$ and $\mathrm{O}$ antigens of Salmonella typhi was deficient. Established humoral response and serum immunoglobulin levels were normal.

Immunosuppression induced by the measles virus, sometimes acting synergistically with immunosuppression due to malnutrition, may contribute to the high prevalence of serious complications seen after measles in tropical developing countries.
\end{abstract}

Measles is still a major cause of death in children of the developing countries (Morley, 1969). In Africa mortality among hospital patients ranges from 5 to $25 \%$, and prolonged morbidity due to secondary infection and malnutrition is frequent (Morley, Woodland, and Martin, 1963; Murphy, 1966). Tuberculosis and moniliasis, infections normally controlled by cell-mediated immune responses, are known to follow measles (Bech, 1962; Smythe et al., 1971). Pyogenic infections, which are usually limited by humoral immune responses, are also frequent and severe in children with measles (Morley, 1969; Taneja, Ghai, and Bhakoo, 1962).

In 1908, von Pirquet showed that the tuberculin reaction became negative during an attack of measles and this observation has been confirmed in natural measles (Starr and Berkovich, 1964) and vaccineinduced measles (Fireman, Friday, and Kumate, 1969). Lymphocyte transformation on stimulation with phytohaemagglutinin (PHA) has been reported to be depressed in natural measles (Kadowaki, Nihira, and Nakao, 1970) but to be normal in vaccine-induced measles (Fireman et al., 1969). Addition of measles virus to lymphocyte cultures did not suppress the response of the cells to PHA

Received 28 April 1973.
(Smithwick and Berkovich, 1966), but we have been unable to find any reports of the effects of measles on humoral immunity in man.

We have investigated the effects of measles infection on the immune system of young children in Nigeria. As immunity is impaired in severe protein-calorie malnutrition (Geefhuysen et al., 1971; Smythe et al., 1971), we have also studied the effects of measles on the nutritional state of the children.

\section{Materials and methods}

Patients. 33 children with acute measles, diagnosed by the presence of Koplik's spots or a typical rash, were studied as outpatients at the Ahmadu Bello University Hospital, Zaria, from February to May 1972. Only patients with a rash less than 4 days old were selected. Patients with malaria parasitaemia or obvious clinical signs of malnutrition were excluded. The mean age of the patients was 31 months (range 7-72 months). 30 patients weighed $80 \%$ or more of the Harvard standard of weight for age (Jelliffe, 1966), 1 patient weighed 75\% of the standard, and the other 2 just under $70 \%$. Judging by the criteria of Morley, Martin, and Allen (1967), none of the children had measles severe enough to warrant hospital admission. Healthy controls were selected from sibs accompanying patients to hospital. They matched the patients for age and weight-for-age. 
The consent of the parents of each child was obtained before they were included in the study.

Schedule. On day 1 the children were examined, weighed, and blood was taken for antibody levels. Intradermal skin tests with $0.5 \mu \mathrm{g}$ purified protein derivative of tuberculin (PPD) ${ }^{\star}$ and $0.1 \mathrm{ml}$ candida and streptococcal antigens (Bencard) were carried out. The patients were sensitized with $2 \mathrm{mg}$ dinitrochlorobenzene (DNCB) dissolved in two drops of acetone and the area was occluded with plaster. They were then immunized with $0.5 \mathrm{ml}$ tetanus toxoid (Burroughs Wellcome) given intramuscularly, and $0.1 \mathrm{ml}$ Salmonella typhi vaccine (Burroughs Wellcome) given intradermally. On the same day patients were given chloroquine syrup, cough mixture, and prescribed procaine penicillin daily for 5 days. 48 hours later (day 3) skin tests were read as positive or negative, induration of $2 \mathrm{~mm}$ or more indicating a positive test. Pyrimethamine was given on day 3 and one week later. 14 days after the start of the investigation children returned for repeat skin tests and a challenge dose of $200 \mu \mathrm{g}$ DNCB. 2 days later (day 16) the children were weighed, blood was taken for antibody levels, and the skin tests were read.

Laboratory methods. Heterophile antibody levels, antibody levels to tetanus toxoid and to the $\mathrm{H}$ and $\mathrm{O}$ antigens of Salm. typhi were measured as previously described (Greenwood et al., 1972). Immunoglobulin levels were determined by radial immunodiffusion using monospecific antisera.t Results were recorded in IU. Albumin and transferrin levels were also determined by radial immunodiffusion using a pool of local sera as a standard. Results were recorded as a percentage of this standard. Lymphocytes were purified and cultured as previously described (Greenwood et al., 1972).

\section{Results}

Established cellular immune responses. The number of patients and controls with positive skin tests to PPD, candida, and streptococcal

*Central Veterinary Laboratory, Weybridge, Surrey.

†Provided by Dr. D. S. Rowe, WHO International Reference Centre for Immunoglobulins, Lausanne. antigens is shown in Table I. On day 3, children with measles had significantly less positive tests to candida $(\mathrm{P}<0.001)$ and streptococcal antigen $(P<0.02)$ than the controls. No patient with measles reacted to PPD.

After repeat skin testing, read on day 16 , the number of reactions in the measles group was comparable to the controls. Among patients with measles the difference in results obtained between day 3 and day 16 was significant for all 3 antigens (Table I).

Induction of cellular immune responses. 31 of the 33 measles patients $(94 \%)$, previously sensitized with $2 \mathrm{mg} D N C B$, responded to a challenge of $200 \mu \mathrm{g}$ DNCB.

The PHA response of lymphocytes from 11 patients with measles was lower than that of the response of 13 healthy controls, but the difference was not statistically significant. On morphological assessment the mean percentage blast cell transformation after stimulation with PHA was $69 \pm 13 \%$ for the patients with measles and $77 \pm 7 \%$ for the controls. On scintillation counting the mean value in counts per minute for stimulated cultures less unstimulated cultures was $15,720 \pm 14,550$ for the measles patients and $22,410 \pm 11,600$ for the controls. A very low PHA response was shown by lymphocytes from one patient with measles but by none of the controls.

Established humoral responses. The mean heterophile antibody level determined on day 1 of the investigation did not differ significantly between the patients with measles and the controls. Likewise no significant difference was found in the immunoglobulin levels of the two groups on day 1 of the investigation (Table II).

Induction of antibody responses. The antibody response to immunization with Salm. typhi

TABLE I

Number of children with positive skin tests to PPD, candida, and streptococcal antigens

\begin{tabular}{|c|c|c|c|c|c|c|}
\hline \multirow{3}{*}{ Group } & \multicolumn{2}{|c|}{ PPD } & \multicolumn{2}{|c|}{ Candida } & \multicolumn{2}{|c|}{ Streptococcus } \\
\hline & \multicolumn{2}{|c|}{ Day } & \multicolumn{2}{|c|}{ Day } & \multicolumn{2}{|c|}{ Day } \\
\hline & 3 & 16 & 3 & 16 & 3 & 16 \\
\hline $\begin{array}{l}\text { Measles } \\
\text { no. }=33 \\
\text { Controls } \\
\text { no. }=34\end{array}$ & $\begin{array}{c}0 \\
4 \\
\text { NS }\end{array}$ & $\begin{array}{c}\quad \begin{array}{l}6 \\
P \\
\text { ND }\end{array} \\
0.05\end{array}$ & $\begin{array}{c}6 \\
21 \\
P<0 \cdot 001\end{array}$ & $P \underset{N D}{<0} \begin{array}{l}19 \\
\text { ND }\end{array}$ & $\begin{array}{c}3 \\
13 \\
P<0.02\end{array}$ & 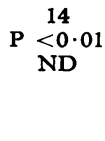 \\
\hline
\end{tabular}

PPD, purified protein derivative of tuberculin; NS, not significant; ND, not done. 
TABLE II

Serum immunoglobulin levels $(I U / m l)$ on day 1 of study (mean $\pm S D)$

\begin{tabular}{l|c|c|c}
\hline & IgA & IgG & IgM \\
\hline $\begin{array}{l}\text { Measles } \\
\text { no. }=33\end{array}$ & $59 \pm 23$ & $143 \pm 49$ & $196 \pm 87$ \\
$\begin{array}{c}\text { Controls } \\
\text { no. }=34\end{array}$ & $56 \pm 27$ & $158 \pm 63$ & $177 \pm 71$ \\
& NS & NS & NS \\
\hline
\end{tabular}

NS, not significant.

vaccine is shown in Table III. Children with measles showed a significantly smaller rise in the titre of antibody to the $\mathrm{H}$ and $\mathrm{O}$ antigens of Salm. typhi than did the controls. 9 of the 33 patients with measles (27\%) showed a response to immunization with tetanus vaccine compared with 17 of 34 controls $(50 \%)$. The difference, however, is not significant $(P=0 \cdot 05-0 \cdot 1)$.

Nutritional and other effects. There was no significant change in the average weight of the children with measles during the period of the investigation. One child subsequently lost more than $10 \%$ of his weight after an attack of diarrhoea and was admitted to hospital. The remaining children made an uneventful recovery.

On day 1 the mean serum albumin level of the patients with measles $(95 \pm 25 \%)$ was significantly lower than that of the control patients $(110 \pm 25 \%)$ $(P<0 \cdot 01)$. However, no significant difference was found in the mean serum transferrin level of the two groups $(120 \pm 31 \%$ for measles and $132 \pm 37 \%$ for controls). Among the patients with measles, no significant difference was found between the mean serum albumin or transferrin levels measured on day 16 compared with those obtained on day 1 .

The mean $\mathrm{Hb}$ level of the children with measles was $10.9 \mathrm{~g} / 100 \mathrm{ml}$ at the start of the study. This had not changed significantly on day $16(11.0 \mathrm{~g} / 100$

TABLE III

Antibody response to immunization with Salm. typhi vaccine

\begin{tabular}{l|l|c}
\hline \multicolumn{1}{c|}{ Group } & H antigen & O antigen \\
\hline $\begin{array}{c}\text { Measles } \\
\text { no. }=33\end{array}$ & $5 \cdot 0 \pm 2 \cdot 1$ & $1.5 \pm 1 \cdot 6$ \\
$\begin{array}{c}\text { Controls } \\
\text { no. }=34\end{array}$ & $6.3 \pm 1.3$ & $3.2 \pm 1.8$ \\
& $\mathbf{P}<0.01$ & $\mathrm{P}<0.001$ \\
\hline
\end{tabular}

Note: Results expressed as mean rise in tube titre in doubling dilutions. $\mathrm{ml})$. The mean leucocyte count for the patients with measles on day 1 was $7617 / \mathrm{mm}^{3}, 54 \%$ of these cells being lymphocytes. No significant change in these values was found on day 16 . One patient had hypochromic red cells, none showed macrocytosis or hypersegmentation of the polymorph neutrophil leucocytes.

\section{Discussion}

Our findings confirmed that measles causes a temporary suppression of the skin reaction to PPD, candida, and streptococcal antigens. However, when the expression of delayed hypersensitivity was suppressed, our patients could still be sensitized normally to DNCB and their lymphocytes responded to stimulation with PHA. Others have previously found a normal PHA response after vaccination with live measles vaccine (Fireman et al., 1969) and after in vitro cultivation of lymphocytes with measles virus (Smithwick and Berkovich, 1966).

The mechanism of this temporary loss of skin reactivity is not clear. Our findings could be explained by a suppressive effect of the measles virus on the production or function of the soluble lymphocyte factors responsible for the final expression of cellular immunity. This type of situation has been described in some patients with chronic mucocutaneous candidiasis who are unable to produce macrophage inhibition factor (Valdimarsson et al., 1970). However, this hypothesis does not explain the finding of Smithwick and Berkovich (1966) that, in vitro, measles virus suppresses the response of lymphocytes to tuberculin but not to PHA. Thus, as an alternate explanation, we suggest that the function of thymusdependent memory cells may be selectively impaired because the measles virus has induced changes in some antigen receptors on their cell surface.

Established humoral immunity was not altered by measles infection. In contrast, the induction of a humoral immune response to the $\mathrm{H}$ and $\mathrm{O}$ antigens of Salm. typhi, and possibly to tetanus toxoid, was deficient. Rinderpest, a virus closely related to measles, has previously been shown to depress the antibody response to chicken erythrocytes in rabbits (Penhale and Pow, 1970). The pathogenesis and pathology of measles and rinderpest are very similar, and it is of interest that latent infections, particularly protozoal, are frequently activated after rinderpest (Curasson, 1932). Suppression of humoral immunity has now been recorded in a number of virus infections of animals and man (Salaman, 1970), but the mechanism of this suppression has not been established. 
Impairment of the expression of cellular immunity during measles may explain why conditions such as tuberculosis and moniliasis are sometimes reactivated by this disease. Defects in humoral immunity, together with local epithelial damage, may account for the high incidence of secondary bacterial infection occurring after measles in the tropics. Bronchopneumonia, particularly staphylococcal, is the commonest cause of death (Williams and Osotimehin, 1970). Other pyogenic infections such as otitis media and purulent infections of the eye and skin are also seen frequently in patients with measles.

The aetiology of cancrum oris is unknown, but this condition is frequently preceded by an attack of measles. Vincent's organism can frequently be isolated from the mouth ulcers in this condition. It is possible that measles-induced suppression of the host's immune response allows this or a similar normally harmless organism to become pathogenic.

We have previously shown that most other febrile illnesses do not suppress cellular or humoral immunity in children seen at Zaria (Greenwood $e t$ al., 1972). Children with malaria, which suppresses humoral immunity (Greenwood et al., 1972), were excluded at the start of the study and all patients and controls were given antimalarial therapy. None of our patients had clinical signs of severe malnutrition, and laboratory investigations showed a slight lowering of the serum albumin as the only effect of measles on the nutrition of our patients. It thus seems likely that the immunosuppression observed in measles is due to a direct effect of the virus and not one mediated by the production of malnutrition or by the induction of a febrile response.

Severe protein-calorie malnutrition impairs the induction of humoral immunity (Brown and Katz, 1965) and the induction and expression of cellular immunity (Smythe et al., 1971; Geefhuysen et al., 1971), probably by different mechanisms than the measles virus. The effect of the two conditions on the immune system may therefore be synergistic, accounting for the frequent and severe infections which occur in malnourished children with measles.

We thank Miss J. C. Boler for technical assistance; $\mathrm{Mr}$. V. Okonkwo; Miss B. Hudson and Mrs. Abdullahi for arranging the follow-up of patients; and Professor $\mathbf{R}$. Prosser for permission to study patients under his care.
Drs. G. L. Asherson and N. Veall provided facilities for scintillation counting at the Clinical Research Centre, Northwick Park, Harrow. This work was supported by grants from the Foreign and Commonwealth Office (Overseas Development Administration) and the M.R.C.

\section{REFERENCES}

Bech, V. (1962). Measles epidemics in Greenland. American Fournal of Diseases of Children, 103, 252.

Brown, R. E., and Katz, M. (1965). Antigenic stimulation in undernourished children. East African Medical fournal, 42, 221.

Curasson, G. (1932). La Peste Bovine. Vigot, Paris.

Fireman, P., Friday, G., and Kumate, J. (1969). Effects of measles vaccine on immunologic responsiveness. Pediatrics, 43, 264.

Geefhuysen, J., Rosen, E. U., Katz, J., Ipp, T., and Metz, J. (1971). Impaired cellular immunity in kwashiorkor with improvement after therapy. British Medical fournal, 4, 527.

Greenwood, B. M., Bradley-Moore, A. M., Palit, A., and Bryceson, A. D. M. (1972). Immunosuppression in children with malaria. Lancet, 1, 169.

Jelliffe, D. B. (1966). The Assessment of the Nutritional Status of the Community, p. 222. World Health Organization, Geneva.

Kadowaki, J., Nihira, M., and Nakao, T. (1970). Reduction of phytohemagglutinin; induced lymphocyte transformation in patients with measles. Pediatrics, 45, 508.

Morley, D. (1969). Severe measles in the tropics. British Medical fournal, 1, 297.

Morely, D. C., Martin, W. J., and Allen, I. (1967). Measles in West Africa. West African Medical fournal, 16, 24.

Morley, D., Woodland, M., and Martin, W. J. (1963). Measles in Nigerian children. Fournal of Hygiene, 61, 115.

Murphy, E. la C. (1966). Measles in Accra 1961-1962. Ghana Medical fournal, $5,58$.

Penhale, W. J., and Pow, I. A. (1970). The immunodepressive effect of rinderpest virus. Clinical and Experimental Immunology, 6, 627.

Salaman, M. H. (1970). Immunodepression by mammalian viruses and plasmodia. Proceedings of the Royal Society of Medicine, 63, 11.

Smithwick, E. M., and Berkovich, S. (1966). In vitro suppression of the lymphocyte response to tuberculin by live measles virus. Proceedings of the Society for Experimental Biology and Medicine, 123, 276.

Smythe, P. M., Schonland, M., Brereton-Stiles, G. G., Coovadia, H. M., Grace, H. J., Loening, W. E. K., Mafoyane, A., Parent, M. A., and Vos, G. H. (1971). Thymolymphatic deficiency and depression of cell-mediated immunity in protein-calorie malnutrition. Lancet, 2, 939.

Starr, S., and Berkovich, S. (1964). Effects of measles, gammaglobulin-modified measles and vaccine measles on the tuberculin test. New England fournal of Medicine, 270, 386.

Taneja, P. N., Ghai, O. P., and Bhakoo, O. N. (1962). Importance of measles to India. American fournal of Diseases of Children, 103, 226.

Valdimarsson, H., Holt, L., Riches, H. R. C., and Hobbs, J. R. (1970). Lymphocyte abnormality in chronic mucocutaneous candidiasis. Lancet, 1, 1259.

von Pirquet, C. (1908). Das Verhalten der kutanen TuberculinReaktion wahrend der Masern. Deutsche Medizinische Wochenschrift, 34, 1297.

Williams, A. O., and Osotimehin, B. (1970). Autopsy study of measles in Ibadan, Nigeria. Ghana Medical fournal, 9, 23.

Correspondence to Dr. H. C. Whittle, Faculty of Medicine, Ahmadu Bello University Hospital, Zaria, Nigeria. 